\title{
Evaluation of Hematological Parameters in the Genetic Prospective in Epileptic Patients of Khyber Pakhtunkhwa
}

This article was published in the following Dove Press journal: Pharmacogenomics and Personalized Medicine

\author{
Nazish Farooq ${ }^{1,2}$ \\ $\mathrm{Niaz} \mathrm{Ali}^{3}$ \\ Shakir Ullah $\mathbb{I D}^{3,4}$ \\ 'Department of Hematology, Institute of \\ Basic Medical Sciences, Khyber Medical \\ University, Peshawar, Pakistan; \\ ${ }^{2}$ Department of Pathology, Khyber \\ Medical College, Peshawar, Pakistan; \\ ${ }^{3}$ Department of Pharmacology, Institute \\ of Basic Medical Sciences, Khyber Medical \\ University, Peshawar, Pakistan; \\ ${ }^{4}$ Department of Pharmacy, University of \\ Malakand, Chakdara, Pakistan
}

Background: Epilepsy is a treatable disease, but unfortunately a treatment gap exists in epileptic patients, especially in developing countries, due to adverse effects of antiepileptic drugs and polymorphisms in genes. Carbamazepine is the most commonly used medication in epilepsy, but is related to some serious and rare adverse effects. The aim of the study was to investigate the effect of folate metabolizing genes (MTHFR and DHFR) polymorphisms on different parameters of complete blood count in patients who were treated with carbamazepine and valproic acid.

Materials and methods: Blood samples from 267 epileptic patients were collected on consent and surrogate consent forms. The blood was analyzed for changes in different parameters in complete blood count through a blood analyzer. The MTHFR gene was genotyped using the RFLP method. The data were analyzed using GraphPad Prism 6.

Results: The homozygous mutant genotype (677CT) of the methylenetetrahydrofolate reductase enzyme (MTHFR C677T) gene significantly affects the level of hemoglobin $(P=0.12)$, hematocrit $(P=0.008)$ and mean corpuscular hemoglobin $(P=0.01)$ compared to the homozygous wild genotype $(677 \mathrm{CC})$ and heterozygous mutant genotype $(677 \mathrm{CT})$ of the MTHFR (C677T) gene. However, the heterozygous genotype (1298AC) of MTHFR (A1298C) gene affect the total leukocyte count $(P=0.037)$ level significantly.

Conclusion: Changes in different parameters of complete blood count were statistically significant but clinically insubstantial decreases in different parameters of complete blood count indexes.

Keywords: AEDs, epilepsy, complete blood count, carbamazepine, MTHFR gene, DHFR gene

\section{Introduction}

Epilepsy is a disorder of the central nervous system characterized by recurrent episodes of seizures. Epilepsy affects individuals without any discrimination, and is still not explored explicitly. ${ }^{1}$ According to the World Health Organization (WHO) estimation, epilepsy affects eight individuals per 1000 population throughout the world. The prevalence of epilepsy is greater in developing countries than that of developed countries. ${ }^{1,2}$ Proper management of epilepsy with suitable antiepileptic drugs can restore seizure-free normal life in approximately $75 \%$ of the affected individuals. ${ }^{3}$ Various factors such as blood sampling timing and procedure, transport and storage of blood sample, difference in subjects and prior physical activities affect hematological values in individuals. Furthermore, inherent variables such as sex, age, occupation, body fluid, genetic profile of patients, diet and environment are more problematic in determination of the hematological level. For these reasons the concept of "normal
Correspondence: Niaz Ali; Shakir Ullah Department of Pharmacology, Institute of Basic Medical Sciences, Khyber Medical University, Peshawar, Pakistan

Email niazpharmacist@yahoo.com; shakir.ibms@kmu.edu.pk 
values" and "normal ranges" has been replaced by reference values and the reference range, which is defined by reference limits and obtained from measurements on the reference population for a particular test. The reference range is also termed the reference interval. ${ }^{4}$ In this scientific advanced era, some advanced measuring electronic counters assess cell size and content effectively, and provide valuable information about different categories of WBCs such as neutrophils, lymphocytes, monocytes, eosinophils and basophils. Furthermore, two other important variables of the complete blood cell count $(\mathrm{CBC})$ are hemoglobin $(\mathrm{Hb})$ and hematocrit (Hct) which provide equivalent information like the RBC count that are used interchangeably. ${ }^{5}$ Parameters of CBC include $\mathrm{Hb}$ (indicator of anemia or polycythemia), $\mathrm{MCV}$ (used in classification of anemias), RBC distribution width (useful in the differential diagnosis of anemia), RBC count (high RBC count used to determine thalassemia trait), platelet count (thrombocytopenia or thrombocythemia) and WBC count with differential (used in diagnosis of acute leukemia and chronic lymphoid or myeloid disorders as well as for the presence of leukopenia and neutropenia). ${ }^{6}$

Most AEDs are associated with different adverse effects. For example, hematologic toxicity, hepatotoxicity, skin disorders and psychological disorders are associated with carbamazepine, lamotrigine, levetiracetam and other AEDs. $^{7}$ These adverse effects become more aggressive if combined with some genetic mutations or polymorphisms in the genome of the human being.

There are more than 20 FDA-approved antiepileptic drugs in the market. Carbamazepine and valproic acid are the bestselling drugs in the world with affordable price that have a good cost-benefit ratio. ${ }^{8}$ Although, carbamazepine and valproic acid are less expensive drugs, but still these drugs are associated with various blood cell abnormalities and other adverse drug reactions. ${ }^{9,10}$ Hematological abnormalities with carbamazepine are reported at a rate of 1:38,000 to $1: 10,800$, which are mentioned in various studies. ${ }^{11}$ Adverse effects of carbamazepine are aplastic anemia, ${ }^{12}$ agranulocytosis, ${ }^{13}$ pancytopenia $^{14}$ and thrombocytopenia. ${ }^{13}$ However, these adverse effects of carbamazepine are very rare. ${ }^{14}$

Changes in hematological parameters are more aggressive if there is some genetic variation and variable drug response. Several polymorphisms of genes encoding for enzymes acting in the remethylation pathway of hmocysteine metabolism such as methylenetetrahydrofolate reductase (MTHFR) C677T have been shown to cause hyperhomocysteinemia (Hhcy) particularly in patients with deficiency of folate, vitamin B6 and vitamin B12. ${ }^{15}$ This variation in genes may also cause some drastic changes in hematological parameters. ${ }^{16}$ As genetic variation is mostly based on ethnicity, and as we have been awarded a research project related to epilepsy and its association with single nucleotide polymorphisms with plasma level of carbamazepine and valproic acid, and subsequently its clinical outcomes, the current work is one aspect of the project to determine the possible effect of MTHFR, gene polymorphisms and carbamazepine on the shift in hematological profile of recipients in the population of Khyber Pakhtunkhwa. The major parts of the body in which DHFR is mainly expressed are the heart, liver, brain and blood. ${ }^{17}$ DHFR and MTHFR gene polymorphisms are commonly associated with folate metabolism and ultimately lead to affect different parameters of CBC.

Since one of the aspects of our project was to know the hematological profile of patients with epilepsy treated with carbamazepine and valproic acid from a genetic perspective, the current work describes the hematological profile shift in patients with epilepsy so far as the DHFR and MTHFR genes are concerned.

\section{Materials and Methods}

\section{Sample Size Calculation}

The patient sample size $(\mathrm{N}=267)$ was calculated using the WHO online sample size calculator at a $95 \%$ level with a confidence interval of $0.06 .^{18}$

\section{Study Design and Duration}

It was a hospital-based prospective cohort study on patients with epilepsy was conducted in the Out Patient Department (OPD) of Lady Reading Hospital (LRH), Peshawar. The study was started in August 2014 and completed in April 2016. Patients with epilepsy were followed up at 3-and 6-month intervals during their treatment.

\section{Target Population}

Newly diagnosed patients with epilepsy from Khyber Pakhtunkhwa were included in the study. Patients who were prescribed carbamazepine therapy were incorporated in the study according to the scheme shown in Figure 1.

\section{Ethical Principles of Research}

Ethical Board approval was obtained from Khyber Medical University, Peshawaraccording to Helsinki Declarations. The 


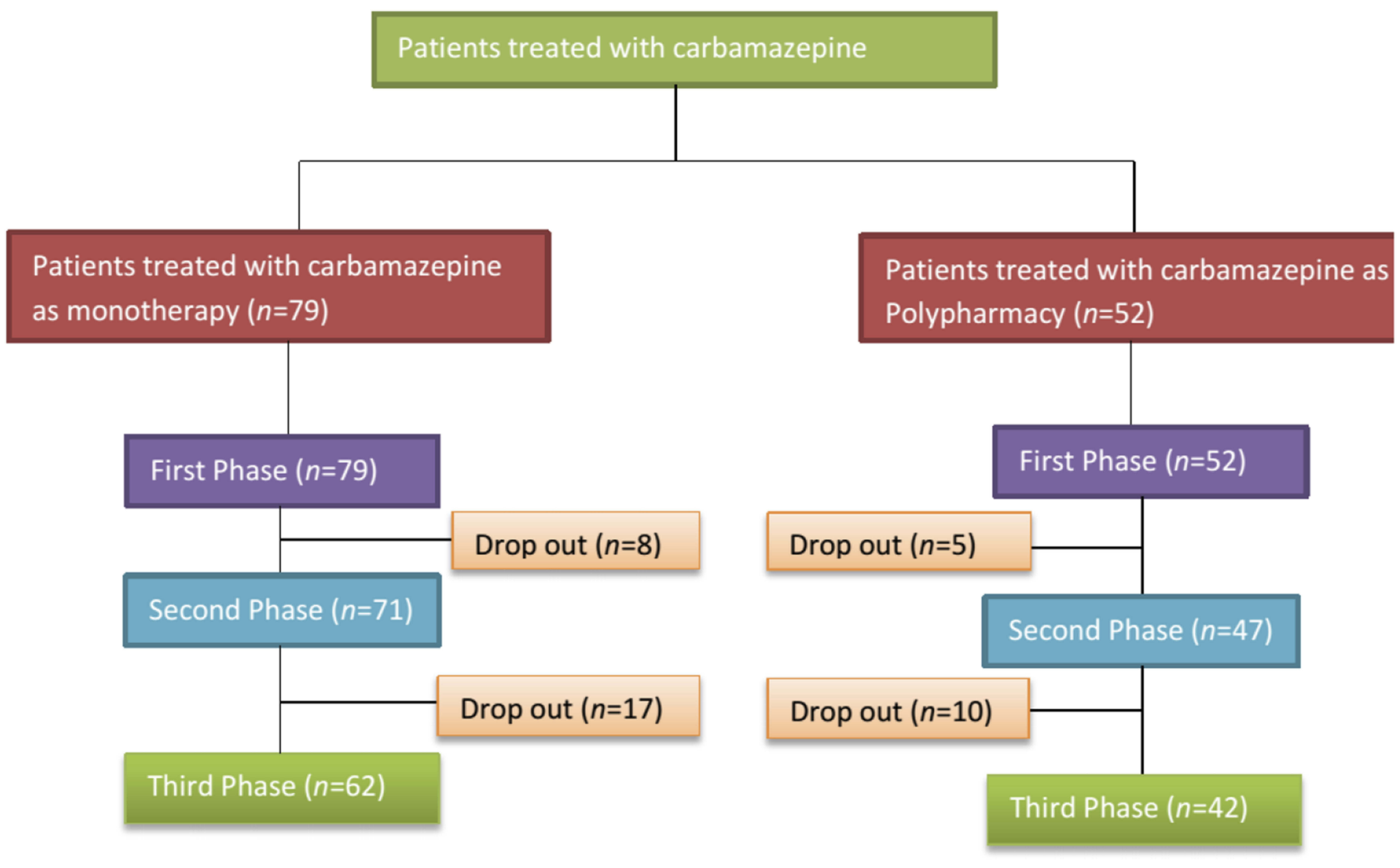

Figure I Patients treated with carbamazepine as monotherapy or in combination with other antiepileptic drugs.

Ethics Board approved the study protocols via no. DIR/ KMU-EB/AC/000047 dated 04/07/2014. Patients who were using carbamazepine provided written informed consent, with parental written informed consent being provided for patients under the age of 18 years with the patient's written informed assent.

\section{Inclusion Criteria}

Newly diagnosed epileptic patients from Khyber Pakhtunkhwa to whom carbamazepine was prescribed as an antiepileptic drug. More, patients who agreed to sign a consent form, an assent form from patients and a surrogate assent form from the guardian of those whose age was below 18 years or who were using carbamazepine as a monotherapy.

\section{Exclusion Criteria}

Those patients excluded from the study had comorbidities or refused to participate in the study.

\section{Collection of Blood and Its Analysis}

The blood samples were collected from epileptic patients in $3 \mathrm{~mL} \mathrm{~K} 3$ tubes containing EDTA (BD vacutainer, NJ, USA) at baseline, after 3 months and 6 months. The collected blood in an EDTA tube (BD vacutainer) was put on a blood roller (Model TYMR-III Blood Roller Mixer, Jiangsu, China) for about $1-2$ mins to dissolve the clot in the tubes. After proper mixing, complete blood count analysis was performed using an automated Hematology Analyzer Model Sysmex KX-21N'M (Asia Pacific Re. Ltd, Japan). About $4 \mu \mathrm{L}$ of blood was automatically sucked by the blood analyzer.

\section{Polymerase Chain Reaction and Genotyping} Exons C677T and A1298C of the MTHFR gene were amplified according to standard protocol. The amplified product size was assessed by running on $2 \%$ agarose gel against a $50 \mathrm{~Pb}$ ladder. The amplified products were then subjected to restriction enzymes (Hinfl, MboII, ApoI and BasMI) for 3 hrs. After proper digestion we ran the digested products on $2.5 \%$ agarose gel and assessed the fragment size of respective exons against a $50 \mathrm{~Pb}$ ladder and determined the frequency of genotypes of respective exons of respective genes, as shown in Figure 2.

\section{Statistical Analysis}

The data were analyzed using statistical software Stata version 12, GraphPad Prism version 5 and Microsoft Excel 2010. The changes in different parameters in 

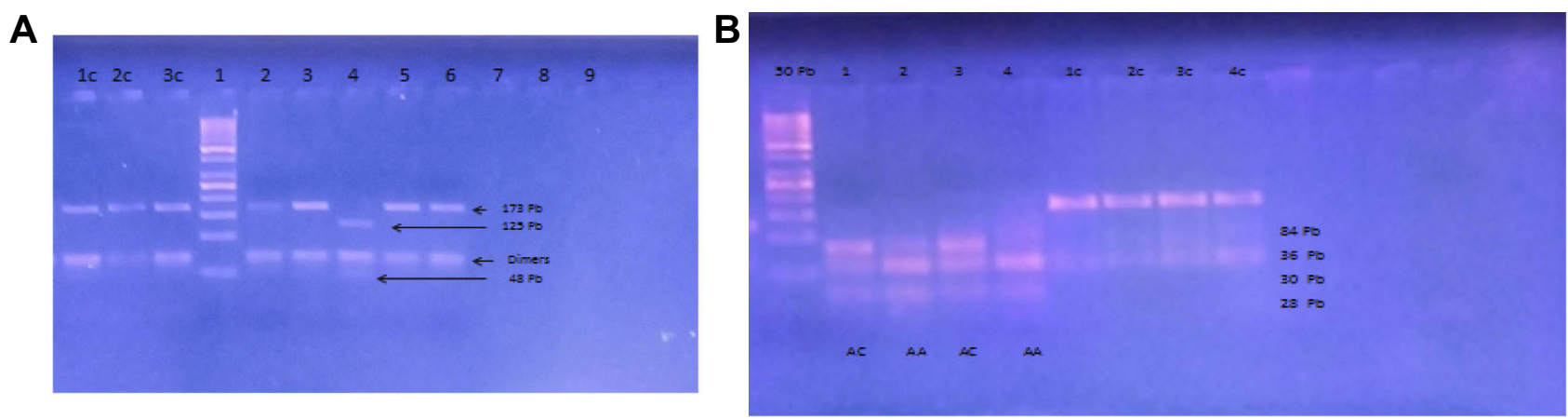

Figure 2 (A) C677T exon. Ic, 2c, 3c control undigested PCR products. I, 50bp ladder, 2,3,5, 6 MTHFR (677CC), 4, MTHFR (677TT). (B) MTHFR AI298C exon. 50 pb, I,3 MTHFR (I298AC), 2, 4 MTHFR (I298AA), Ic.2c.3c control undigested PCR products.

complete blood count were determined by two-way ANOVA followed by Bonferroni's post hoc test. Twoway ANOVA was used to compare changes in different parameters of complete blood count with respect to gender and dose of carbamazepine and in different variants of MTHFR genes. More, changes in different hematological values were also evaluated with respect to the different phases of the study.

\section{Results}

\section{Characteristics of Epileptic Patients Using Carbamazepine}

The patients were evaluated in three phases (phase $1=79$, phase $2=68$ and phase $3=58$ ) on the basis of their follow up during treatment. Hence, the characteristics of patients with epilepsy are presented in Table 1. There were $38(47.44 \%)$ males and $41(52.56 \%)$ females in phase 1, $32(46.48 \%)$ males and $35(53.52 \%)$ females in phase 2, and 25 $(43.55 \%)$ males and $33(56.45 \%)$ females in phase 3 respectively. The mean age of the patients was $18.24 \pm 0.39,17.84$ \pm 0.97 and $18.08 \pm 1.10$ in phase 1 , phase 2 and phase 3 . The mean dose of carbamazepine was $451.28 \pm 15.45 \mathrm{mg}$ /day in phase $1,453.52 \pm 16.39 \mathrm{mg} /$ day in phase 2 and 454.83 $\pm 17.15 \mathrm{mg} /$ day in phase 3 as shown in Table 1 .

\section{The Effect of Gender on Complete Blood Count During Treatment of Epilepsy with Carbamazepine}

Changes in all parameters of complete blood count were determined by gender and in three phases of study in patients with epilepsy who were treated with carbamazepine as monotherapy. Two-way ANOVA followed by Bonferroni's post hoc test was used to compare the changes in complete blood count in male and female patients. More, changes were also compared from the first phase to the second and third phases of the study. Change in the level of $\mathrm{Hb}(P=0.04)$, HCT $(P=0.03)$ and $\mathrm{MCH}(P=0.02)$ was statistically significant but clinically was non-significant. Their levels were affected by gender as well as different phases of treatment. However, the mean level of $\mathrm{Hb}$ was decreased during the last phases of treatment as shown in Table 2. More, change in the level of TLC $(P=0.03)$ and platelets $(P=0.02)$ was statistically significant during the second and third phases of the study compared to the first phase of the study, but changes were found within the reference ranges. More, changes in the level of other parameters of complete blood count were not significant in gender as well as during different phases of study as shown in Table 2 .

Table I Demographic Features of Epileptic Patients Using Carbamazepine

\begin{tabular}{|l|l|l|l|l|}
\hline \multirow{2}{*}{ Group } & \multicolumn{2}{|l|}{ Gender } & \multirow{2}{*}{ Mean Age (Years) } & \multirow{2}{*}{ Mean Dose of Carbamazepine } \\
\cline { 2 - 3 } & Male & Female & & \\
\hline Phase I $(\mathrm{n}=79)$ & $38(47.44 \%)$ & $41(52.56 \%)$ & $18.24 \pm 0.39$ & $451.28 \pm 15.45 \mathrm{mg} / \mathrm{day}(200-800 \mathrm{mg} / \mathrm{day})$ \\
Phase 2 $(\mathrm{n}=68)$ & $32(46.48 \%)$ & $35(53.52 \%)$ & $17.84 \pm 0.97$ & $453.52 \pm 16.39 \mathrm{mg} / \mathrm{day}(200-800 \mathrm{mg} / \mathrm{day})$ \\
Phase 3 $(\mathrm{n}=58)$ & $25(43.55 \%)$ & $33(56.45 \%)$ & $18.08 \pm 1.10$ & $454.83 \pm 17.15 \mathrm{mg} / \mathrm{day}(200-800 \mathrm{mg} / \mathrm{day})$ \\
\hline
\end{tabular}


Table 2 Changes in the Level of All Parameters of Complete Blood Count in Gender During Different Phases of Study

\begin{tabular}{|c|c|c|c|c|c|c|c|}
\hline \multirow[t]{3}{*}{ Parameters } & \multicolumn{7}{|c|}{ Gender $(n=79)$} \\
\hline & \multicolumn{3}{|l|}{ Male } & \multicolumn{3}{|l|}{ Female } & \multirow{2}{*}{$\begin{array}{l}P \text { value } \\
\text { (C) }\end{array}$} \\
\hline & $\begin{array}{l}\text { Ist Phase } \\
(n=38)\end{array}$ & $\begin{array}{l}\text { 2nd Phase } \\
(n=32)\end{array}$ & $\begin{array}{l}\text { 3rd Phase } \\
(n=25)\end{array}$ & $\begin{array}{l}\text { Ist Phase } \\
(n=4 I)\end{array}$ & $\begin{array}{l}\text { 2nd Phase } \\
(n=35)\end{array}$ & $\begin{array}{l}\text { 3rd Phase } \\
(n=33)\end{array}$ & \\
\hline $\mathrm{Hb}(\mathrm{g} / \mathrm{dL})$ & 13.58 & 12.43 & 12.15 & 13.19 & 11.95 & 11.03 & $0.04 *$ \\
\hline HCT (\%) & 45.27 & 43.66 & 42.92 & 44.71 & 43.89 & 42.82 & $0.03 *$ \\
\hline MCV (fl) & 89.57 & 87.28 & 88.04 & 88.32 & 88.37 & 88.24 & 0.51 \\
\hline $\mathrm{MCH}(\mathrm{pg})$ & 29.03 & 28.94 & 29.20 & 28.68 & 28.40 & 28.85 & $0.02 *$ \\
\hline $\mathrm{MCHC}(\%)$ & 34.22 & 34.28 & 34.18 & 34.16 & 33.87 & 33.90 & 0.55 \\
\hline TLC (cells $/ \mu \mathrm{L})$ & 5139 & 5345 & 5238 & 4993 & 5046 & 4982 & $0.03 *$ \\
\hline Plts (cells/ $/ \mathrm{L}$ ) & 395,324 & $4|5,58|$ & 388,440 & 382,707 & 405,686 & 384,576 & $0.02 *$ \\
\hline Neutrophils (\%) & 61.35 & 59.65 & 59.96 & 59.46 & 60.31 & 59.67 & 0.81 \\
\hline Lymphocytes (\%) & 34.76 & 36.35 & 36.04 & 36.73 & 35.66 & 36.33 & 0.90 \\
\hline Monocytes (\%) & 2.24 & 1.710 & 1.920 & 1.95 & 1.972 & 2.061 & 0.56 \\
\hline Eosinophil (\%) & 1.83 & 2.031 & 2.172 & 2.23 & 2.031 & 1.893 & 0.99 \\
\hline
\end{tabular}

Note: *Two-way ANOVA was used and it was found that the changes were significant at the last stage of therapy and change was higher in female compared to male patients in the last stages of treatment.

\section{The Effect of Different Doses of Carbamazepine on Complete Blood Count During Different Phases of Study}

The effect of different doses of carbamazepine on the level of all parameters of complete blood count was evaluated by two-way ANOVA followed by Bonferroni's post hoc test. The effect of different doses of carbamazepine on the level of all parameters of complete blood count was observed at different stages of study and compared, and the changes are shown in Table 3. Change in the level of $\mathrm{Hb}(P=0.002)$, HCT $(P=0.035), \mathrm{MCV}(P=0.025), \mathrm{MCH}$ $(P=0.024)$ and TLC $(P=0.002)$ was statistically significant at a dose of $800 \mathrm{mg} /$ day or more at a late stage of therapy but clinically was non-significant as shown in Table 3. More, changes in the remaining parameters of complete blood count were not significant at different doses of carbamazepine as well as at different stages of treatment as shown in Table 3.

\section{The Effect of the MTHFR Gene on All Parameters of Complete Blood Count During Treatment with Carbamazepine}

The effect of two single nucleotide polymorphisms rs1801133 (C677T) and rs180131 (A1298C) of the MTHFR gene on all parameters of complete blood count was assessed using two-way ANOVA followed by a post hoc test as shown in Tables 4 and 5. The change in the level of all parameters of complete blood count was compared genotypically as well as phase wise during the study. Change in level of $\mathrm{Hb}(P=0.12)$, HCT $(P=0.008)$, and $\mathrm{MCH}(P=0.01)$ was statistically significant in the homozygous mutant genotype (TT) as compared to the homozygous wild genotype (CC) and heterozygous mutant genotype (CT) of the MTHFR (C677T) gene but the change was within the reference ranges. More, the changes were also becoming statistically significant with the passage of time. Furthermore, changes in other parameters of complete blood count were not significant in different genotypes of the MTHFR (C677T) gene as well during the three phases of study as shown in Table 4. However, changes in different parameters of CBC in different genotypes of the MTHFR (A1298C) gene were not significant during the study at a late stage of therapy as shown in Table 5. Although, the change in TLC $(P=0.037)$ was statistically significant in the heterozygous genotype (AC) of the MTHFR (A1298C) exon at the third phase of treatment but the changes were within the reference ranges as shown in Table 5 .

\section{Discussion}

The mean age of patients was $18.24 \pm 0.39$ years and the mean dose of carbamazepine was $451.28 \pm 15.45 \mathrm{mg} /$ day. Carbamazepine was used in different doses $(200-800 \mathrm{mg} /$ day) as monotherapy. Changes in levels of $\mathrm{Hb}, \mathrm{HCT}$ and $\mathrm{MCH}$ were significant in gender during the study and were also affected by the duration of treatment but were not clinically significant. Similarly, high doses of carbamazepine affect the level of Hb, HCT, MCV, MCH and TLC, but 


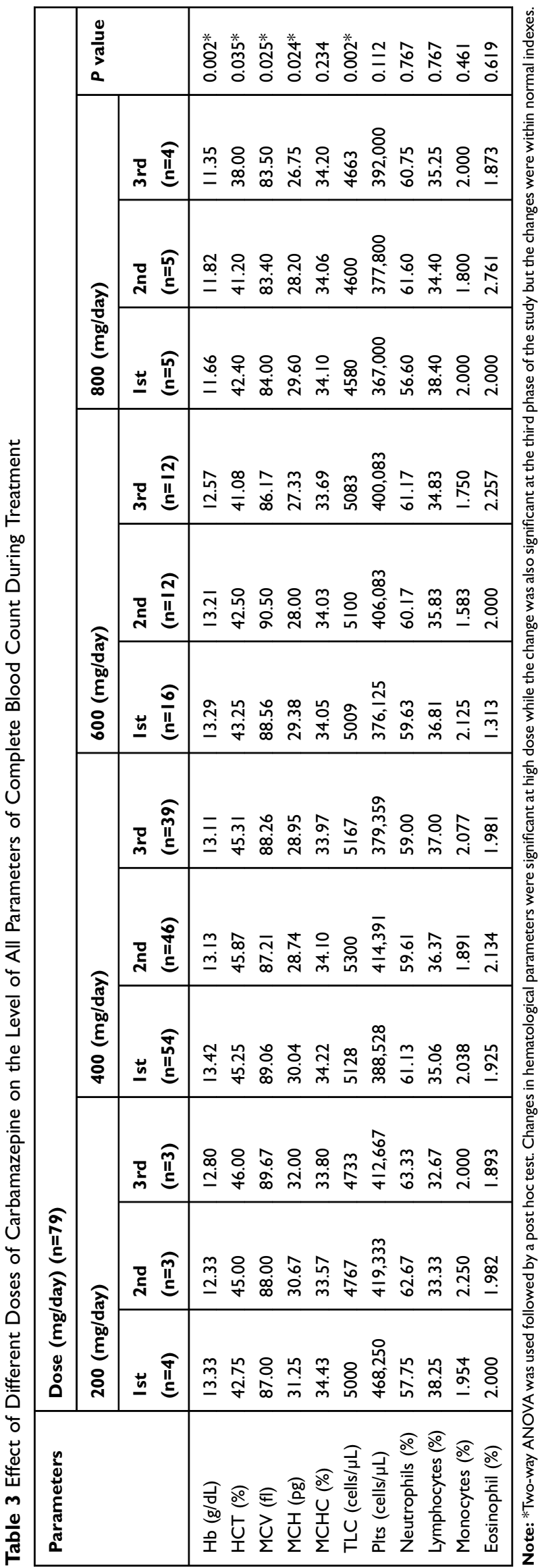

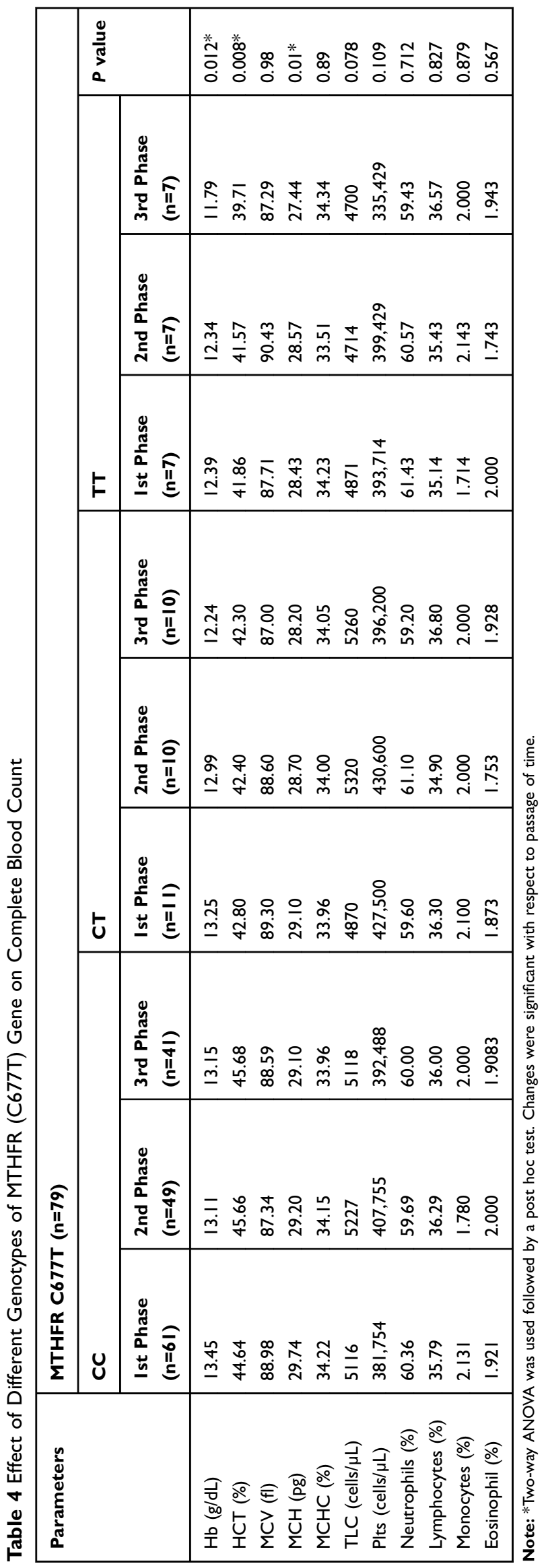


Table 5 Effect of Genotypes of MTHFR (AI298C) Gene on Complete Blood Count

\begin{tabular}{|c|c|c|c|c|c|c|c|c|c|c|}
\hline \multirow[t]{3}{*}{ Parameters } & \multicolumn{10}{|c|}{ MTHFR AI298C (n=79) } \\
\hline & \multicolumn{3}{|l|}{ AA } & \multicolumn{3}{|l|}{ AC } & \multicolumn{3}{|l|}{ CC } & \multirow[t]{2}{*}{$P$ value } \\
\hline & $\begin{array}{l}\text { Ist } \\
\text { Phase } \\
(n=63)\end{array}$ & $\begin{array}{l}\text { 2nd } \\
\text { Phase } \\
(n=52)\end{array}$ & $\begin{array}{l}\text { 3rd } \\
\text { Phase } \\
(n=46)\end{array}$ & $\begin{array}{l}\text { Ist } \\
\text { Phase } \\
(n=10)\end{array}$ & $\begin{array}{l}\text { 2nd } \\
\text { Phase } \\
(n=9)\end{array}$ & $\begin{array}{l}\text { 3rd } \\
\text { Phase } \\
(n=8)\end{array}$ & $\begin{array}{l}\text { Ist } \\
\text { Phase } \\
(n=6)\end{array}$ & $\begin{array}{l}\text { 2nd } \\
\text { Phase } \\
(n=5)\end{array}$ & $\begin{array}{l}\text { 3rd } \\
\text { Phase } \\
(n=4)\end{array}$ & \\
\hline $\mathrm{Hb}(\mathrm{g} / \mathrm{dL})$ & 13.3 & 13.06 & $13.1 \mid$ & 13.29 & 12.94 & 12.49 & 13.15 & 12.72 & 11.88 & 0.07 \\
\hline HCT (\%) & 44.8 & 45.92 & $45.4 I$ & 45.80 & 45.22 & 47.25 & 44.33 & 43.00 & 39.75 & 0.12 \\
\hline $\operatorname{MCV}(\mathrm{fl})$ & 89.3 & 88.04 & 88.33 & 88.00 & 87.11 & 86.75 & 86.33 & 86.33 & 89.00 & 0.64 \\
\hline $\mathrm{MCH}(\mathrm{pg})$ & 28.9 & 28.30 & 29.20 & 30.87 & 30.67 & 28.13 & 29.50 & 28.80 & 27.25 & 0.25 \\
\hline $\mathrm{MCHC}(\%)$ & 34.2 & 34.01 & 33.99 & 33.80 & 34.44 & 33.88 & 34.27 & 33.98 & 34.68 & 0.94 \\
\hline TLC (cells $/ \mu \mathrm{L})$ & 5040 & 5152 & 5029 & 4990 & 5122 & 5313 & 5417 & 5660 & 5375 & $0.037^{*}$ \\
\hline Plts (cells/ $\mu \mathrm{L}$ ) & 389,532 & 402,135 & 389,239 & 403,300 & 432,222 & 378,875 & 355,667 & 456,200 & 366,500 & 0.12 \\
\hline Neutrophils (\%) & 60.56 & 60.02 & 59.67 & 57.90 & 59.33 & 60.50 & 62.33 & 61.00 & 59.75 & 0.96 \\
\hline Lymphocytes (\%) & 35.58 & 35.96 & 36.33 & 38.30 & 36.67 & 35.50 & 33.83 & 35.00 & 36.25 & 0.98 \\
\hline Monocytes (\%) & 2.032 & 1.811 & 1.913 & 2.300 & 2.222 & 2.500 & 2.333 & 1.600 & 2.000 & 0.17 \\
\hline Eosinophil (\%) & 1.973 & 2.141 & 2.001 & 1.983 & 1.783 & 1.951 & 2.000 & 2.371 & 1.892 & 0.60 \\
\hline
\end{tabular}

Note: *Two-way ANOVA was used followed by a post hoc test. Changes become significant with the passage of time.

changes were associated with duration of treatment. Change in the level of TLC and platelet was also associated with duration of treatment but clinically unsubstantial. More, change in the level of $\mathrm{Hb}, \mathrm{HCT}$ and $\mathrm{MCH}$ were also statistically significant in the homozygous variant of MTHFR C677T exon and change in the level of TLC was associated with the heterozygous variant $(\mathrm{AC})$ and homozygous variant (CC) of MTHFR A1298C exon at a late stage of therapy. MTHFR has no direct effect on complete blood count, but changes occurred with the passage of time as is mentioned in the already existing literature. According to the previous literature a slight decline in hemoglobin level is associated with the use of carbamazepine. ${ }^{14}$ It has been found that monotherapy of AEDs has no significant association with the changes in $\mathrm{Hb}$ level and some other blood parameters. ${ }^{19}$ Studies are available showing that MTHFR gene polymorphisms can affect the vitamin B6 and folate, and ultimately decrease the $\mathrm{Hb}$ level of the patient and lead to anemia. ${ }^{20,21}$ However, carbamazepine, valproic acid and other AEDs are responsible for bone marrow suppression leading to blood problem(s) like thrombocytopenia, leucopenia and aplastic anemia via anti-folic activity. ${ }^{22}$ Bailey and Ayling's study shows that patients using CBZ, VPA and other AEDs significantly reduce their Plts count. ${ }^{23}$ The anti-folate properties of carbamazepine result in a decrease of $\mathrm{Hb}$ level and an increase in homocysteine level which affect some metabolic pathways. ${ }^{24}$ Our finding shows some agreement with some studies in relation to biochemical and hematological toxicities with the use of $\mathrm{CBZ}$ and $\mathrm{VPA},{ }^{25-29}$ but also has coincidence with some studies that AEDs have no significant association or a less toxic effect on hematological parameters. ${ }^{30,31}$ It has been found that our study results are coinciding with the existing literature and no major distractions were seen. The next part of the project is to explore the role of the DHFR gene on hematological parameters and folate metabolism.

\section{Conclusion}

It has been found that changes in different hematological parameters were statistically significant with the passage of time in female patients. Furthermore, changes in different parameters of complete blood count were also significant at a high dose ( $\geq 800 \mathrm{mg} /$ day) of carbamazepine in a late stage of therapy. More, $\mathrm{Hb}, \mathrm{HCT}, \mathrm{MCH}$ and TLC levels significantly change with respect to the MTHFR gene in the third phase of the study. So, changes in some parameters of complete blood count were statistically significant but clinically insubstantial, and decreases in different parameters of complete blood count indexes were observed during the study.

\section{Abbreviations}

AEDs, Antiepileptic drugs; CBZ, Carbamazepine; $\mathrm{Hb}$, Hemoglobin; TLC, Total leucocyte count; Plts, Platelets; $\mathrm{HCT}$, Hematocrit; MCV, Mean corpuscular volume; $\mathrm{MCH}$, Mean corpuscular hemoglobin; MCHC, Mean corpuscular hemoglobin concentration; pg, Picograms; fl, Femtoliters; MTHFR, Methylenetetrahydrofolate reductase enzyme; DHFR, Dihydrofolate reductase. 


\section{Recommendations}

It is recommended that epileptic patients of different cohorts should be followed for at least 5 years and their complete blood count should be monitored at different intervals of time. Patients should be focused on who are on a high dose of carbamazepine and it is advisable to genotype the MTHFR gene for possible variants.

\section{Acknowledgments}

The authors are very thankful to the Directorate of Science and Technology, Khyber Pakhtunkhwa for funding this project. We are also very thankful to Professor Dr. Adnan Gul Khan, Dr. Shabeer, and Dr. Bakht Jan who helped us during our research in the Neurology Department of Lady Reading Hospital Peshawar.

\section{Disclosure}

The authors report no conflicts of interest in this work.

\section{References}

1. World Health Organization. Global Burden of Epilepsy and the Need for Coordinated Action at the Country Level to Address Its Health, Social and Public Knowledge Implications; 2015.

2. Burneo JG, Tellez-Zenteno J, Wiebe S. Understanding the burden of epilepsy in Latin America: a systematic review of its prevalence and incidence. Epilepsy Res. 2005;66(1):63-74. doi:10.1016/j.eplepsyres. 2005.07.002

3. Brodie MJ. Antiepileptic drug therapy the story so far. Seizure. 2010;19(10):650-655. doi:10.1016/j.seizure.2010.10.027

4. Lewis SM, Bain BJ, Bates I, Dacie JV. Dacie and Lewis Practical Haematology. Elsevier Health Sciences; 2006.

5. Behrens JA, Brown WP, Gibson DF, Detter JC. Whole-blood hemoglobin determinations: a comparison of methodologies. Am J Clin Pathol. 1979;72(6):904-908. doi:10.1093/ajcp/72.6.904

6. Tefferi A, Hanson CA, Inwards DJ. How to interpret and pursue an abnormal complete blood cell count in adults. Mayo Clin Proc. 2005;80(7):923-936.

7. Aronson JK. Side Effects of Drugs Annual: A Worldwide Yearly Survey of New Data and Trends in Adverse Drug Reactions. Elsevier; 2005.

8. Perucca P, Gilliam FG. Adverse effects of antiepileptic drugs. Lancet Neurol. 2012;11(9):792-802. doi:10.1016/S1474-4422(12)70153-9

9. Bertolino J. Carbamazepine. What physicians should know about its hematologic effects. Postgrad Med. 1990;88(1):183-186. doi:10.1080/ 00325481.1990 .11716370

10. Tohen M, Castillo M, Zarate C Jr. Blood dyscrasias with carbamazepine and valproate: a pharmacoepidemiological study of 2228 patients at risk. Women. 1995;13(72.2):6-85.7.

11. Olcay L, Pekcan S, Yalnizoğlu D, Büyükpamukçu M, Yalaz K. Fatal agranulocytosis developed in the course of carbamazepine therapy. A case report and review of the literature. Turk J Pediatr. 1994;37(1):73-77.

12. Luchins DJ. Fatal agranulocytosis in a chronic schizophrenic patient treated with carbamazepine. Am J Psychiatry. 1984;141(5):687-688.

13. Holmes G. Carbamazepine: Adverse Effects. Antiepileptic Drugs. Philadelphia: Lippincott-Raven; 2002:284-297.
14. Isojärvi JI, Pakarinen AJ, Myllylä VV. Basic haematological parameters, serum gamma-glutamyl-transferase activity, and erythrocyte folate and serum vitamin B 12 levels during carbamazepine and oxcarbazepine therapy. Seizure. 1997;6(3):207-211. doi:10.1016/ S1059-1311(97)80007-6

15. Salomon O, Rosenberg N, Zivelin A, et al. Methionine synthase A2756G and methylenetetrahydrofolate reductase $\mathrm{A} 1298 \mathrm{C}$ polymorphisms are not risk factors for idiopathic venous thromboembolism. Hematol J. 2001;2 (1):38-41. doi:10.1038/sj.thj.6200078

16. Lalouschek W, Aull S, Serles W, et al. The relation between erythrocyte volume and folate levels is influenced by a common mutation in the methylenetetrahydrofolate reductase (MTHFR) gene (C677T). $J$ Invest Med. 2000;48(1):14-20.

17. Banka S, Blom HJ, Walter J, et al. Identification and characterization of an inborn error of metabolism caused by dihydrofolate reductase deficiency. Am J Human Genetics. 2011;88(2):216-225. doi:10.1016/ j.ajhg.2011.01.004

18. Lwanga SK, Lemeshow S. Sample size determination in health studies: a practical manual. Available from: https://apps.who.int/ iris/handle/10665/40062. Accessed date 4 August 2014.

19. Bhosale UA, Loharkar NR, Yegnanarayan R, Quraishi N. Study of effects of antiepileptic therapy on various biochemical and hematological parameters patients suffering of epilepsy. Int J Basic Clin Pharmacol. 2014;3(1):79-85. doi:10.5455/2319-2003.

20. Bagley PJ, Selhub J. A common mutation in the methylenetetrahydrofolate reductase gene is associated with an accumulation of formylated tetrahydrofolates in red blood cells. Proc Nat Acad Sci. 1998;95(22):13217-13220. doi:10.1073/pnas.95.22.13217

21. Christensen B, Arbour L, Tran P, et al. Genetic polymorphisms in methylenetetrahydrofolate reductase and methionine synthase, folate levels in red blood cells, and risk of neural tube defects. Am J Med Genet. 1999;84(2):151-157. doi:10.1002/(ISSN)1096-8628

22. Brosh K, Matok I, Sheiner E, et al. Teratogenic determinants of first-trimester exposure to antiepileptic medications. J Popul Ther Clin Pharmacol. 2010;18:e89-98.

23. Bailey SW, Ayling JE. The extremely slow and variable activity of dihydrofolate reductase in human liver and its implications for high folic acid intake. Proc Nat Acad Sci. 2009;106(36):15424-15429. doi:10.1073/pnas.0902072106

24. Selhub J. Homocysteine metabolism. Аnпи Rev Nutr. 1999;19 (1):217-246. doi:10.1146/annurev.nutr.19.1.217

25. Bachmann T, Bertheussen K, Svalheim S, et al. Haematological side effects of antiepileptic drug treatment in patients with epilepsy. Acta Neurol Scand. 2011;124(s191):23-27. doi:10.1111/ane.2011.124. issue-s191

26. Handoko KB, Souverein PC, Van Staa TP, et al. Risk of aplastic anemia in patients using antiepileptic drugs. Epilepsia. 2006;47 (7):1232-1236. doi:10.1111/j.1528-1167.2006.00596.x

27. Farkas V, Szabo M, Renyi I, Kohlheb O, Benninger C. Temporary pure red-cell aplasia during valproate monotherapy: clinical observations and spectral electroencephalographic aspects. J Child Neurol. 2000;15(7):485-487. doi:10.1177/088307380001500713

28. Jang SH, Choi EK, Eun SH, Kim SJ. Changes of body weight and lipid profiles according to apolipoprotein E polymorphism in children with antiepileptics. Korean J Pediatr. 2002;45(1):88-94.

29. Sankar R. Initial treatment of epilepsy with antiepileptic drugs pediatric issues. Neurology. 2004;63(10 suppl 4):S30-S9. doi:10.1212/ WNL.63.10_suppl_4.S30

30. Pee DH, Park YK, Eun BL, Park SH, Kim SK. The hematologic effect of antiepileptic drug. Korean J Pediatr. 1997;40(2):217-224.

31. Aliyu H, Ambali JOASF, Abdulkadir UZ. Effects of administration of carbamazepine and/or phenytoin on haematological parameters in wistar rats. Afr J Pharm Pharmacol. 2013;7(23):1585-1591. doi:10.5897/AJPP2013.3611 


\section{Publish your work in this journal}

Pharmacogenomics and Personalized Medicine is an international, peer-reviewed, open access journal characterizing the influence of genotype on pharmacology leading to the development of persona-

lized treatment programs and individualized drug selection for improved safety, efficacy and sustainability. This journal is indexed on the American Chemical Society's Chemical Abstracts Service (CAS). The manuscript management system is completely online and includes a very quick and fair peer-review system, which is al easy to use. Visit http://www.dovepress.com/testimonials.php to read real quotes from published authors.

Submit your manuscript here: https://www.dovepress.com/pharmacogenomics-and-personalized-medicine-journal 